\title{
nature
}

\section{The increasing opacity of gene therapy}

The influence of commercial interests is highlighted by recent reports of deaths during trials of gene therapies. The loosening of public scrutiny of such studies needs to be reconsidered.

A decade ago, when gene therapy burst on the scene promising potential cures for all manner of diseases, researchers made a shrewd political choice. By submitting to the notion that studies of a highly experimental therapy should be publicly scrutinized, they bought the goodwill of the American people and their trust that, whatever the bumps in the road, scientists and those who supported them were committed to patients' safety.

Ominously for gene therapy's public image, a more secretive tendency seems to be taking root among some gene therapists and their sponsors. It has emerged that at least six recent deaths in patients participating in gene-therapy trials have not been reported to the National Institutes of Health (NIH), despite federal guidelines requiring such reporting. Separately, the drug company Schering-Plough reported numerous serious side effects in cancer patients, but insisted that they be kept confidential (see Nature 402, 6; 1999).

The deaths do not include the only one so far definitively linked to gene therapy, that of 18-year-old Jesse Gelsinger, who died in September at the University of Pennsylvania. Commendably, researchers there disclosed details fully and promptly (see Nature 401, 517; 1999).

The six unreported deaths, documented on 3 November by The Washington Post, occurred in trials being run by Ronald Crystal and Jeffrey Isner, of Cornell Medical Center in Manhattan and Tufts University in Boston, respectively. The founders of separate biotechnology companies, the two are competing fiercely in a race to use gene therapy to grow new cardiac blood vessels. Both defend their decisions not to notify the NIH of the deaths, arguing that they were attributable not to gene therapy, but to the patients' underlying illnesses. Traditionally, that is a determination that researchers have left to the NIH's Recombinant DNA Advisory Committee (RAC), whose mandate is to debate the ethics of gene therapy in public. Sponsors and investigators are also required to report deaths and adverse events to the Food and Drug Administration (FDA), and those involved in these cases say they did so. But the FDA keeps such reports confidential.

Why should researchers and companies be challenging established practice in a field that up to now has prided itself on its transparency? The answers are unsettling.

First, the field, which initially was three-quarters NIH-funded, is now heavily underwritten by industry, and the corporate concern for commercial secrecy has begun to make itself felt. Companies loathe disclosing anything that could hurt share prices. But corporate strongarming of the RAC goes further: at least one company has pressured NIH officials to keep entire protocols off the public record. Fortunately, it has so far failed. But corporations may be finding a way around their problem. More and more companies - albeit still only a fraction of those involved - are funding their experiments entirely privately, which means they can evade RAC reporting requirements completely.

There is another troubling aspect to this new secrecy. Three years ago, Harold Varmus, the NIH director, stripped the RAC of its power to approve gene-therapy protocols. That left the RAC as an important, but less powerful, venue for public debate on the experiments (see Nature 384, 297; 1996). The real power to determine their fate was left entirely behind closed doors at the FDA.

It is difficult not to conclude that the RAC's new toothlessness has left researchers and companies feeling too relaxed about their ability to flout its guidelines with impunity. If this is the outcome of what was essentially a compromise by Varmus — industry had been agitating for the RAC's complete abolition, and activists for its retention perhaps it is time that that decision was revisited.

\section{A cold wind from the East}

\section{Charges faced by a Ukrainian scientist could have a chilling effect on the future of international collaboration.}

ife has been difficult for scientists in states of the former Soviet Union since the fall of communism. Those who have not left to work elsewhere have often only been able to maintain active research through collaboration with Western researchers. But even this, it seems, carries its risks As a result of his participation in various European and US programmes, Sergei Piontkovski, a Ukrainian oceanographer who works at the Institute of Biology of the Southern Seas in Sebastopol, is facing charges of communicating 'secret' information to the West and illegally handling foreign currency (see Nature 401, 835 \& 402, 6; 1999, and page 110 in this issue).

There is always the possibility that, unknown to his foreign collaborators, Piontkovski has been involved in such nefarious activities. But to most of those familiar with him and with the case, his 'crime' seems to have been no more than exchanging research data with foreign research teams on topics such as the distribution of plankton, and receiving support in hard currency from Western funding agencies.
By one account, the actions against him are the result of purely local initiatives, not of a clamp-down by central government. Piontkovski's international activities have been formally approved by the Ukrainian authorities in Kiev. It is to the credit of the Ukrainian Academy of Sciences that it has spoken out in his defence, as well as that of colleagues who are also facing scrutiny by the local secret police.

But the affair should not be dismissed as a little local difficulty, as it has profound international implications. If the charges against Piontkovski are upheld by the court later this month, the result will inevitably have a chilling effect on scientific collaboration, not only with the Ukraine, but also with its neighbouring states, many of whose economies - and scientific communities - are already in a fragile enough state. Hopefully, reason will prevail, and any charges against Piontkovski and his colleagues will be dropped with the same speed with which they were initially made. 